\title{
O DANO MORAL E SUA INERÊNCIA AOS DIREITOS DA PERSONALIDADE
}

\section{José Luiz de Moura Faleiros Júnior*}

Sumário: 1 Introdução; 2 Abordagem conceitual sobre o dano moral; 2.1 Breve escorço histórico; $2.2 \mathrm{O}$ dano moral no ordenamento jurídico brasileiro; 2.2.1 O dano moral no Código Civil de 1916; 2.2.2 O dano moral na Constituição da República de 1988; 3 Fundamentos para a reparação do dano moral; $3.1 \mathrm{O}$ caráter punitivo do dano moral. 3.2 Valoração do dano moral; 4 Os direitos da personalidade em face do dano moral; $5 \mathrm{~A}$ questão dos danos morais sofridos pela pessoa jurídica; 6 Conclusão.

Resumo: As dificuldades na compreensão da extensão e das características dos direitos da personalidade, que careciam de um mecanismo viável de tutela jurídica, fizeram com que o Direito evoluísse ao alvedrio desses direitos. Nesse sentido, o desenvolvimento da doutrina dos danos morais representou o elo que faltava para unir a compreensão que se tinha de tais direitos a um mecanismo sancionatório, cuja importância na sistemática civil atual, logo fez surgir um questionamento acerca da possibilidade de sua existência fora do âmbito dos direitos da personalidade. Neste trabalho, serão estudados o conceito de dano moral, sua origem histórica, seus fundamentos, seu modo de quantificação, bem como sua posição no ordenamento brasileiro, para, ao final, contrapô-lo aos direitos da personalidade.

Palavras-chave: Dano moral. Direitos da personalidade. Constituição da República de 1988. Responsabilidade civil. Inerência.

\footnotetext{
* Pós-graduando em Direito pela Faculdade de Direito Prof. Damásio de Jesus - FDDJ. Graduado em Direito pela Universidade Federal de Uberlândia - UFU. Advogado. E-mail: jose_luiz_jr@ hotmail.com
} 


\section{Introdução}

Adoutrina sempre encontrou dificuldades na compreensão da extensão e das características dos direitos da personalidade, que eram vislumbrados por outras ciências, mas careciam de um mecanismo viável de tutela jurídica, diante das situações cotidianas que geravam a lesão. Nos últimos séculos, a dogmática civilista ocupou-se fortemente de dar tratamento jurídico aos bens que compõem a esfera patrimonial dos indivíduos, e, com isso, os direitos da personalidade restaram ao alvedrio de um tratamento legal mais cuidadoso.

Nesse sentido, o desenvolvimento da doutrina dos danos morais foi o elo que faltava para unir a compreensão que se tinha dos direitos da personalidade a um mecanismo sancionatório, apto a impor punição adequada ao descumprimento do dever absoluto, imponível a todos, da abstenção de lesar a esfera patrimonial dos direitos da personalidade de outrem.

A inserção dos direitos da personalidade e dos danos morais no texto da Constituição da República consagra a evolução pela qual ambos os institutos jurídicos passaram ao longo das últimas décadas. Além disso, por ostentarem cunho não-patrimonial, os direitos da personalidade encontram excelente campo de aplicação em relação aos danos morais, ambos apresentam a mesma natureza jurídica.

Tamanha é a importância do dano moral na sistemática civil atual que logo surge o questionamento acerca da possibilidade de sua existência fora do âmbito dos direitos da personalidade, assunto que se pretende analisar neste trabalho.

Atentando-se aos imperativos da brevidade, a explanação ora proposta pautar-se-á pela análise conceitual do dano moral, seguida de breve escorço histórico, no intuito de estabelecer uma premissa sobre a inserção desse instituto na dogmática moderna da responsabilidade civil. Em seguida, analisar-se-á, em breves linhas, como o ordenamento jurídico brasileiro trata desse instituto, por meio de um estudo mais detido do Código Civil de 1916 e da Constituição da República de 1988.

Ademais, serão estabelecidos alguns critérios de aferição e quantificação do dano moral, pontuando os fundamentos para sua reparação, inclusive o caráter punitivo, fulcrado na teoria do desestímulo. Finalmente, os direitos da personalidade serão abordados, destacando-se seu conceito e suas características, para, em conclusão, estabelecer uma contraposição de tais direitos ao dano moral e constatar a inerência destes em relação àqueles. 


\section{Abordagem conceitual sobre o dano moral}

Insofismavelmente, a integridade individual, considerada de maneira ampla, é composta de várias categorias de bens, das quais se destaca a categoria dos bens personalíssimos, que representam o plexo de qualidades anímicas formadoras do indivíduo.

Nesse sentido, tem-se a enorme importância do estudo do dano moral, que pode causar prejuízos psíquicos e orgânicos de toda ordem, levando o indivíduo a um estado de sucateamento existencial, acarretando-lhe insegurança, perda de autoestima, de confiança e de vivacidade, além de propiciar-lhe abalos econômicos de toda monta.

Aparecida Amarante, enfatizando a importância do estudo específico da honra na compreensão do instituto do dano moral, cita um excerto da obra do autor italiano Domenico Barbero, salientando que "na conservação da honra, se pode reconhecer a integridade moral da pessoa, assim como na conservação de suas vida e incolumidade se reconhece sua integridade física" (tradução nossa). ${ }^{1}$ A autora conclui sua ponderação com uma referência a Francesco Carrara, para quem a honra individual liga-se à própria dignidade, à estima ou à boa opinião de outrem sobre o indivíduo, que, inserido no seio social, tem a honra como virtude que lhe garante boa reputação e animus existencial. ${ }^{2}$

Por sua vez, indo diretamente ao ponto, os autores franceses André Tunc e os irmãos Henri e León Mazeaud pontuam que o dano moral é "o que não atinge de modo algum o patrimônio e causa tão só uma dor moral à vítima", enquanto René Savatier o define como "todo sofrimento humano que não resulta de uma perda pecuniária" (tradução nossa). ${ }^{4}$

Augusto Zenun aduz que, para amenizar a situação de danos dessa natureza, é preciso que se proporcione à vítima "meios adequados para um alevantamento seguro, eficaz, talvez lento e demorado, às vezes mais

1 BARBERO, Domenico. Sistema instituzionale del diritto privato italiano. 2. ed., Turim: Unione Editrice Torinese, 1949. v. I, p. 491 apud AMARANTE, Aparecida Imaculada. Responsabilidade civil por dano à honra. 2. ed. Belo Horizonte: Del Rey, 1994, p. 53.

2 CARRARA, Francesco. Programma del corso di diritto criminale: parte speciale. 5. ed. Lucca: Tipografia di G. Canovetti, 1889, p. 5 apud AMARANTE, Aparecida Imaculada. Responsabilidade civil por dano à honra. 2. ed. Belo Horizonte: Del Rey, 1994, p. 55.

3 MAZEAUD, Henri; MAZEAUD, León; TUNC, André. Traité théorique et pratique de la responsabilité civile, délictuelle et contractuelle. 3. ed. Paris: Librairie du Recueil Sirey, 1938, p. 424.

4 SAVATIER, René. Traité de la responsabilité civile en droit français. Paris: Librairie Génêrale de Droit et de Jurisprudence, 1951. t. I, n. 525, p. 92. 
rápido, desde que não seja fugaz e enganador", de forma a "se aplicar à reparabilidade daquilo que a dor causa ou deixa gravado em cada qual, num somatório de males invadindo a alma, mordendo o coração". ${ }^{6}$

Pelo que se lê, conclui-se que a moral está situada no plano nãopatrimonial do conjunto de bens jurídicos do indivíduo, representando tudo aquilo que se relaciona com a alma, a intimidade e todo o arcabouço de caracteres que formam a personalidade. Deve, portanto, ser analisada sob seu aspecto subjetivo, levando em conta diversos elementos da personalidade individual. ${ }^{7}$

A melhor doutrina cuida da distinção conceitual entre os danos patrimoniais e os danos morais (não-patrimoniais). Em poucas palavras, os primeiros são o verdadeiro e próprio juízo econômico e os segundos, o sofrimento psíquico ou moral, as dores, angústias e frustrações infligidas ao ofendido. ${ }^{8}$

Buscando substrato na doutrina italiana, Yussef Said Cahali cita a obra de Adriano de Cupis, segundo o qual o "dano não-patrimonial, em conformidade com sua negativa expressão literal, é todo dano privado que não adentra ao dano patrimonial, tendo por objeto um interesse nãopatrimonial, vale dizer, relativo a bem não-patrimonial" (tradução nossa). ${ }^{9}$

Ainda buscando fontes do direito italiano, Cahali cita Alfredo Minozzi e acentua que a distinção entre o dano patrimonial e o não-patrimonial não diz respeito ao dano em sua origem, mas em seus efeitos. Segundo o autor italiano, quando se fala em danos não-patrimoniais, entende-se que há uma referência aos danos que não atingem o patrimônio material da pessoa. O conteúdo dos danos não-patrimoniais não é o dinheiro ou qualquer coisa que possa ser reduzida a dinheiro, mas a sensação dolorosa vivenciada pela pessoa. ${ }^{10}$

Com isso, mostra-se essencial a busca, nas origens históricas do dano moral, dos elementos que culminaram com a previsão de sua reparabilidade para pôr fim à antiquada noção de que o dano moral corresponde pura e

\footnotetext{
ZENUN, Augusto. Dano moral e sua reparação. 3. ed. Rio de Janeiro: Forense, 1995, p. 2.

ZENUN, Augusto. Dano moral e sua reparação. 3. ed. Rio de Janeiro: Forense, 1995, p. $2 .$.

ZENUN, Augusto. Dano moral e sua reparação. 3. ed. Rio de Janeiro: Forense, 1995, p. 4.

8 CAHALI, Yussef Said. Dano moral. 3. ed. São Paulo: Revista dos Tribunais, 2005, p. 21.

9 DE CUPIS, Adriano. Il danno: teoria generale della responsabilità civile. Milão: Giuffrè, 1970. v. I, n. 10, p. 51, apud CAHALI, Yussef Said. Dano moral. 3. ed. São Paulo: Revista dos Tribunais, 2005, p. 22.

${ }^{10}$ MINOZZI, Alfredo. Studio sul danno non patrimoniale (danno morale). 3. ed. Milão: Societtà Editrice Libraria, 1917, §13, p. 40-41, apud CAHALI, Yussef Said. Dano moral. 3. ed. São Paulo: Revista dos Tribunais, 2005, p. 22.
} 
simplesmente à dor momentânea, esquecendo-se dos efeitos maléficos e indeléveis que podem ser causados a longo prazo no indivíduo.

Através de uma análise histórica, é possível perceber que, nas mais variadas civilizações, sempre se buscou mecanismos para a instituição da responsabilidade civil, no intuito de promover o ressarcimento de quem fosse lesado, e, com o dano moral, não foi diferente. Assim, a seguir, serão pontuados alguns dos eventos históricos que culminaram na criação desse instituto e sua evolução ao longo dos tempos.

\subsection{Breve escorço histórico}

O nascedouro do que hoje se define como dano moral deu-se no Código de Hamurabi ${ }^{11}$, no qual dois capítulos eram especificamente destinados aos casos de injúria e difamação da família, embora o sistema punitivo daquela época não admitisse penas exclusivamente pecuniárias. Punia-se, primordialmente, pela retaliação.

Já o Código de Manu, instituidor das premissas básicas do Hinduísmo, era mais sólido no tocante às penas pecuniárias, que eram previstas para determinados atos contrários à moral religiosa ${ }^{12}$ da sociedade da Índia. Tal legislação, embora fortemente influenciada por um conjunto de ideologias favoráveis a uma casta sacerdotal centralizadora, representou certa evolução em relação às punições meramente físicas do Código de Hamurabi.

Outra análise interessante diz respeito ao tratamento da matéria no Alcorão, o livro sacro do Islamismo, que, apesar de admitir o princípio da lex talionis, também traz uma série de medidas compensatórias, voltadas à diminuição do chamado direito de vindita (vingança), incentivando as pessoas a repelirem o ódio e utilizarem-se do perdão e da misericórdia na busca pela reparação dos danos. ${ }^{13}$

\footnotetext{
${ }^{11}$ Descoberto na cidade de Suza, pelo arqueólogo Jacques Morgan, o Código de Hamurabi foi o que primeiro instituiu a lei de talião, ou "lex talionis", no latim (lex: lei e talio, de talis: tal, idêntico), que, por sua própria análise etimológica, permite concluir o modo como era aplicada: pela reciprocidade do crime e da pena, por simples retaliação, que se consagrou na expressão "olho por olho, dente por dente". (Cf. SILVA, Américo Luís Martins da. O dano moral e a sua reparação civil. São Paulo: Revista dos Tribunais, 1999, p. 69)

12 O Código de Manu trazia algumas previsões curiosas de penas pecuniárias para determinados atos que, para o Hinduísmo, revelavam-se como verdadeiras afrontas morais. É o exemplo da passagem do $\$ 224$ do livro VIII, que autorizava o próprio rei a impor pesada multa àquele que desse em casamento, sem prévio aviso ao interessado, uma "donzela com defeitos". (Cf. SILVA, Américo Luís Martins da. O dano moral e a sua reparação civil. São Paulo: Revista dos Tribunais, 1999, p. 66).

${ }^{13}$ SILVA, Wilson Melo da. O dano e sua reparação. 3. ed. Rio de Janeiro: Forense, 1983, p. 26.
} 
Segundo Wilson Melo da Silva:

No Alcorão, onde, em tese, se aceitava, também, o princípio do talião, mais se acentuam esses abrandamentos introduzidos à aspereza da norma legalizadora da vingança. As compensações de natureza econômica para substituírem o direito de vindita são aí abundantes e mesmo estas são, não raro, desaconselhadas em nome do perdão. ${ }^{14}$

Alguns exemplos interessantes também são encontrados na antiga Grécia, quase sempre ilustrados sob a faceta politeísta daquele povo, como no alegórico conto em que Ésquines reprovou publicamente seu rival Demóstenes, em virtude de este ter recebido de Mídias certa quantia de dinheiro como reparação por uma bofetada. ${ }^{15}$ Noutro conto, em sua obra Odisséia, Homero descreve uma assembleia realizada pelos deuses pagãos para deliberar sobre um caso de reparação decorrente de crime de adultério praticado pelos deuses Ares e Afrodite, que causou danos morais ao deus Hefesto, esposo desta. ${ }^{16}$

Casos assim, materializados em verdadeiras rapsódias, não produziam efeitos jurídicos para os cidadãos gregos da época, mas já refletiam uma mentalidade, ainda adormecida em relação ao Direito, que denota a aceitação do dano moral como elemento inerente às relações humanas.

Embora o conceito arcaico de dano moral ainda germinasse em tais legislações, foi no direito romano que esse instituto encontrou, efetivamente, seu nascedouro para o mundo do Direito. Yussef Said Cahali salienta que Giorgio Giorgi ${ }^{17}$, assim como Windscheid ${ }^{18}$, inspirados pelas lições romanas, já enfatizavam que o conceito da actio injuriarum aestimatoria representa verdadeiro embrião do conceito moderno de dano moral, por permitir, ao lesado, pleitear, perante o prcetor, uma certa quantia para ressarcimento das injúrias sofridas.

A Lei das XII Tábuas (Lex Duodecim Tabularum), simplificada que era, já previa a abrangência reparatória ao preconizar a célebre premissa de que "se alguém causa dano premeditadamente, que o repare", aqui incluído,

${ }^{14}$ SILVA, Wilson Melo da. O dano e sua reparação. 3. ed. Rio de Janeiro: Forense, 1983, p. 26-27.

${ }^{15}$ REIS, Clayton. Dano moral. 4. ed. Rio de Janeiro: Forense, 1995, p. 13, nota ${ }^{\circ} 4$.

${ }^{16}$ REIS, Clayton. Dano moral. 4. ed. Rio de Janeiro: Forense, 1995, p. 13, nota n ${ }^{0} 5$.

${ }^{17}$ GIORGI, Giorgio. Teoria delle obbligazioni nel diritto moderno italiano. 7. ed., Florença: Fratelli Cammeli, 1909. t. V, n. 161, p. 272-275, apud CAHALI, Yussef Said. Dano moral. 3. ed. São Paulo: Revista dos Tribunais, 2005, p. 30.

18 WINDSCHEID, Bernhard. Diritto delle pandette. Trad. Carlo Fadda e Paolo Emílio Bensa. Turim: UTET, 1925. v. II, §472, p. 427, apud CAHALI, Yussef Said. Dano moral. 3. ed. São Paulo: Revista dos Tribunais, 2005, p. 30. 
evidentemente, o dano moral e sua ulterior reparação, que encontrava limites estabelecidos no $\S 9^{\circ}$ da Tábua VII, na qual constava que "aquele que causar dano leve indenizará 25 asses". ${ }^{19-20}$

A Lex Aquilia, embora seja comum dizer que se referia exclusivamente à reparação dos danos corporais, apresenta, segundo alguns autores, uma noção sobre os danos morais, quando analisada analogicamente. Augusto Zenun é o principal defensor dessa tese e proclama que a clássica estrutura da legislação aquiliana, fundamentada sobre a simples imputabilidade, pressupunha juízo sincrético de análise do nexo de causalidade entre o fato do ofensor e o dano, desprezandose o dolo nos casos de furto, roubo e injúria. Diz o doutrinador que, se o furto, por exemplo, fosse reparado com pena equivalente, esta poderia ser não corporal. ${ }^{21}$

Já no direito canônico, o dano moral era encarado segundo a violação dos dogmas inerentes ao Cristianismo. Casos como o rompimento da promessa de casamento, que era fato gerador de uma obrigação sacra, resultavam na necessidade de reparação por parte de quem dava causa à ruptura do enlace matrimonial.

Zenun pondera que, "já àquela época, o direito canônico reconhecia o dano moral - como não poderia, obviamente, deixar de sê-lo, exigindose-lhe a reparação, que podia ser civil ou espiritual, conforme o catalogar do Código Canônico". ${ }^{22}$

\subsection{O dano moral no ordenamento jurídico brasileiro}

No Brasil, em especial ao longo da segunda metade do século XX, vislumbrou-se notável avanço da questão da reparação dos danos morais, tanto na doutrina quanto na jurisprudência, principalmente após a promulgação da Constituição da República de 1988, que tratou expressamente do dano moral.

19 ZENUN, Augusto. Dano moral e sua reparação. 3. ed. Rio de Janeiro: Forense, 1995, p. 6.

${ }^{20}$ Exemplificando o modo incipiente como os romanos já encaravam a questão da reparação moral, Clayton Reis reproduz história narrada por Max Kaser: "conta-se que um certo Lucius Veratius se deliciava verberando (esbofeteando) com a sua mão o rosto dos cidadãos livres que encontrava na rua. Atrás de si vinha um seu escravo entregando 25 asses a todos em que o daminus batia". (KASER, Max. Romisches Privatrecht. 9. ed. Munique: C.H. Beck Verlag, 1976, §§50, p. 199202, apud REIS, Clayton, Op. cit., p. 18, nota $\mathrm{n}^{\mathrm{o}} 13$ ).

21 ZENUN, Augusto. Dano moral e sua reparação. 3. ed. Rio de Janeiro: Forense, 1995, p. 9.

22 ZENUN, Augusto. Dano moral e sua reparação. 3. ed. Rio de Janeiro: Forense, 1995, p. 11. 
Embora a doutrina já discutisse questões pontuais sobre o instituto, havia notável divergência entre aqueles que negavam qualquer possibilidade de reparação do dano moral, os que admitiam unicamente a reparação de seus reflexos de natureza patrimonial, e aqueles que reconheciam a existência do instituto, per se, como parte do ordenamento jurídico, dividindo-se, porém, entre os que defendiam a tese de sua ampla reparação e os que não a reconheciam.

Juristas como Tito Fulgêncio, Nélson Hungria, Érico Vieira de Almeida e Frederico Sussekind se filiavam à tese de que o dano puramente moral não era, em nenhuma hipótese, ressarcível. Alguns dos mais comuns argumentos invocados por essa corrente eram a inexistência jurídica do dano moral, que, à época, ainda não pertencia ao direito positivado, a indeterminação do número total de vítimas atingidas pela conduta causadora de dano moral e a imoralidade da compensação de uma dor interna com dinheiro, situação que era vista como abominável em tempos passados. ${ }^{23}$

Wilson Melo da Silva, aprofundando-se no estudo da questão, destaca oito argumentos apresentados pelos defensores dessa tese:

$1^{\text {a) }}$ Falta de um efeito penoso durável; $2^{\mathrm{a}}$ ) A incerteza, nessa espécie de danos, de um verdadeiro direito violado; $3^{\mathrm{a}}$ ) A dificuldade de descobrir-se a existência do dano; $4^{\mathrm{a}}$ ) A indeterminação do número de pessoas lesadas; $5^{\mathrm{a}}$ ) A impossibilidade de uma rigorosa avaliação em dinheiro; $6^{\mathrm{a}}$ ) A imoralidade de compensar uma dor com dinheiro; $7^{\mathrm{a}}$ ) $\mathrm{O}$ ilimitado poder que se tem de conferir ao juiz; $8^{\mathrm{a}}$ ) A impossibilidade jurídica de se admitir tal reparação. ${ }^{24}$

A segunda corrente, defensora da tese da reparação apenas dos reflexos patrimoniais dos danos morais, era visível na jurisprudência dos tribunais, emanada de juristas como José Antônio de Sousa Gomes, João Olavo Elói de Andrade, Enéas Galvão, dentre outros, que, embora admitissem a reparação dos reflexos patrimoniais, negavam, assim como a corrente anterior, a existência jurídica do dano moral puro.

Para melhor esclarecer esse conceito, é mister trazer à baila a lição de Júlio Bernardo do Carmo:

Diz-se puro ou direto o dano moral quando lesiona um interesse tendente à satisfação ou gozo de um bem jurídico não-patrimonial, ou seja, são diretos os danos morais quando a lesão afeta um bem jurídico contido nos direitos de

${ }^{23}$ SILVA, Wilson Melo da. O dano e sua reparação. 3. ed. Rio de Janeiro: Forense, 1983, p. 336

${ }^{24}$ SILVA, Wilson Melo da. O dano e sua reparação. 3. ed. Rio de Janeiro: Forense, 1983, p. 337. 
personalidade, como a vida a integridade corporal, a honra, a própria imagem, ou mesmo quando atinge os atributos da pessoa, como o nome, a capacidade, o estado de família. ${ }^{25}$

Esse conceito perdurou durante pouco tempo. Porém, a doutrina logo passou a definir que o dano é moral ou material, não tendo sentido a alcunha do dano moral puro, motivo pelo qual tal designação caiu em desuso e foi logo abandonada.

Aguiar Dias destaca que os danos morais apresentam algumas características em comum com os danos patrimoniais de origem moral ou afetiva, o que levou boa parcela da doutrina à confusão, dando azo ao argumento de que só são reparáveis os reflexos patrimoniais dos danos morais. ${ }^{26}$

A tese defendida por essa corrente também foi duramente criticada, em especial porque a noção de dano moral foi se aprimorando de forma gradativa. Augusto Zenun assevera que, “conseguintemente, razão não têm os que só admitem a reparação do dano moral quando há repercussão econômica, porque não se trata de pagar a dor, os sofrimentos, mas de dar ao lesado os meios para-derivativos, com que se aplacam ou afugentam esses males". ${ }^{27}$

Destarte, a vertente que admite a reparação dos danos morais foi a que prosperou no Brasil, superando as proposições anteriores. Para os adeptos dessa teoria, o dano moral deveria ser invariavelmente reparado, ainda que imperfeito, dada a natureza subjetiva do bem jurídico lesado, cuja consequência - a dor - é de caráter íntimo e eminentemente espiritual, eis que negativas, dolorosas e deprimentes as manifestações que provoca.

Um dos principais argumentos sustentados pelos defensores dessa doutrina é o princípio da essencialidade do dano como elemento da responsabilidade civil. Sem um dano, diziam, não há responsabilidade civil, e, partindo de tal premissa, consideravam que o dever reparatório deveria ser amplo, contemplando todos os tipos de danos efetivamente causados.

Sobre essa corrente, Aguiar Dias salienta que:

Com efeito, a unanimidade dos autores convém em que não pode haver responsabilidade sem a existência de um dano, e é verdadeiro truísmo sustentar esse princípio, porque, resultando a responsabilidade civil em obrigação de ressarcir, logicamente não pode concretizar-se onde não há que reparar. ${ }^{28}$

\footnotetext{
${ }^{25}$ CARMO, Júlio Bernardo do. O dano moral e sua reparação no âmbito do direito civil e do trabalho. In: Revista LTr, São Paulo, mar. 1996, p. 304.

${ }^{26}$ DIAS, José de Aguiar. Da responsabilidade civil. 11. ed. Rio de Janeiro: Renovar, 2006, p. 428.

27 ZENUN, Augusto. Dano moral e sua reparação. 3. ed. Rio de Janeiro: Forense, 1995, p. 73.

${ }^{28}$ DIAS, José de Aguiar. Da responsabilidade civil. 11. ed. Rio de Janeiro: Renovar, 2006, p. 393.
} 
Para essa corrente, o dano moral deixou de ser encarado como um mecanismo que serviria apenas para aplacar ou eliminar as consequências da dor e do sofrimento oriundos da lesão, passando a ostentar, além da função compensatória, uma função punitiva. Nesse sentido, o dano moral encontra seu epicentro na fusão dessas duas forças: une-se o caráter punitivo ao caráter compensatório, o que constitui um dano bipartido, com dupla finalidade, que serve a um interesse social multifacetado, promovendo uma reparação à vítima pelo mal sofrido e inibindo o ofensor da futura prática de atos semelhantes.

Esse novo paradigma, que tem suas forças estabelecidas no panorama principiológico da ampla reparação dos danos causados, está pacificado perante a doutrina e tem encontrado fortes sustentáculos na jurisprudência moderna.

\subsubsection{O dano moral no Código Civil de 1916}

O Código Civil de 1916 - Lei no 3.071/16 -, embora não se filiasse a uma ou outra corrente sobre a reparação dos danos morais, deixava em aberto a questão de sua reparabilidade. Com isso, embora seja inegável que o vetusto código admitia a reparação de tais danos, por certo, fazia-o com "muita timidez", como bem assevera Américo Luís Martins da Silva ${ }^{29}$, uma vez que os principais fundamentos jurídicos de tal reparação repousavam somente em seu art. 76, que preconizava o seguinte:

Art. 76. Para propor, ou contestar uma ação, é necessário ter legítimo interesse econômico ou moral.

Parágrafo único. O interesse moral só autoriza a ação quando toque diretamente ao autor, ou à sua família. (destaques nossos)

Se o interesse moral, íntimo que é, autoriza a ação quando toca diretamente seu autor, ou sua família, por decorrência lógica, era admitida a reparação dos danos causados a tais interesses, quando efetivamente comprovados.

O cerne da questão em foco é que não se pode confundir o interesse de agir, que é condição da ação estudada pelo Direito Processual Civil, com o interesse que forma o conteúdo do direito subjetivo e que se procura assegurar efetivamente com o exercício da ação. Os defensores dessa

${ }^{29}$ SILVA, Américo Luís Martins da. O dano moral e a sua reparação civil. São Paulo: Revista dos Tribunais, 1999, p. 181. 
tese cuidavam de enfatizar que o interesse de agir não se confunde com a própria substância do direito material, e, com isso, criavam uma barreira à consideração do dano moral. ${ }^{30}$

Por outro lado, sempre existiram aqueles que visualizavam como certa a reparação do dano moral com base no preceito acima transcrito. Cahali, por exemplo, explica que inexistia regra geral que permitisse deduzir silogisticamente a obrigação de reparação do dano moral, mas, nem por isso, permite-se a conclusão de que tal omissão legislativa isentaria o ofensor de reparar o dano moral que causasse. ${ }^{31}$

Como se não bastasse, vários outros dispositivos do Código Civil de 1916 também suscitavam dúvidas acerca da questão, tais como os arts. $1.537,1.545,1.547,1.548,1.549,1.551$ e 1.553 . Nenhum desses, contudo, trazia explicitamente qualquer menção à reparação dos eventos casuísticos narrados como danos morais, porém, permitiam interpretação dúbia e controversa entre os doutrinadores.

\subsubsection{O dano moral na Constituição da República de 1988}

É sabido que a noção de dano moral existiu desde bem antes da Constituição da República Federativa do Brasil de 1988, mas foi com seu advento que, finalmente, pôs-se fim a qualquer dúvida ainda remanescente a respeito da possibilidade de reparação de tais danos no ordenamento jurídico brasileiro, elevando-os à condição de direitos fundamentais, com status de cláusula pétrea, conforme previsão específica contida no art. $5^{\circ}$, incisos $\mathrm{V}$ e $\mathrm{X}$, in verbis:

Art. $5^{\circ}$ Todos são iguais perante a lei, sem distinção de qualquer natureza, garantindo-se aos brasileiros e aos estrangeiros residentes no País a inviolabilidade do direito à vida, à liberdade, à igualdade, à segurança e à propriedade, nos termos seguintes:

$[\ldots]$

$\mathrm{V}$ - é assegurado o direito de resposta, proporcional ao agravo, além da indenização por dano material, moral ou à imagem;

$[\ldots]$

$\mathrm{X}$ - são invioláveis a intimidade, a vida privada, a honra e a imagem das pessoas, assegurado o direito a indenização pelo dano material ou moral decorrente de sua violação. (destaques nossos)

30 ZENUN, Augusto. Dano moral e sua reparação. 3. ed. Rio de Janeiro: Forense, 1995, p. 80.

${ }^{31}$ CAHALI, Yussef Said. Dano moral. 3. ed. São Paulo: Revista dos Tribunais, 2005, p. 55-56. 
Até o advento da notável Magna Carta de 1988, admitia-se a reparação dos danos morais, mas eram nítidas as divergências entre os doutrinadores; com a promulgação da nova constituição, porém, teve início um vertiginoso aumento na quantidade de legislações infraconstitucionais embasadas na inaugural principiologia do instituto.

Clayton Reis destaca que diversas legislações infraconstitucionais vêm sendo editadas no país, desde que sacramentada a garantia de reparação dos danos morais, dentro do rol do art. $5^{\circ}$ da Constituição da República, ampliando o leque de opções para a propositura de ações indenizatórias. O autor destaca os casos do Código de Defesa do Consumidor (Lei $\mathrm{n}^{\circ}$ 8.078/1990), que expressamente admite a reparação de danos patrimoniais e morais, em seu art. $6^{\circ}$, incisos VI e VII, e do Estatuto da Criança e do Adolescente (Lei $n^{\circ}$ 8.069/1990), que assegura a crianças e adolescentes o direito à integridade física, psíquica e moral, em seus arts. 17 e 201, incisos V, VIII e IX. ${ }^{32}$

Sobre isso, Rodrigo Mendes Delgado destaca que:

qualquer celeuma a respeito do tema em análise, esvaiu-se e desfragmentou-se, como as areias de uma duna no deserto, que está constantemente sob influência do vento, com a edição da Constituição Federal de 1988, que, em seu art. $5^{\circ}$ - cláusula pétrea - incisos $\mathrm{V}$ e X, fincaram, definitivamente, a reparabilidade dos danos morais. ${ }^{33}$

Em outras palavras, a responsabilidade é decorrência lógica do livre-arbítrio estatuído no ordenamento jurídico democrático, garantindo amplas liberdades aos indivíduos, que, se exercidas de modo nocivo, gerando prejuízos a outrem, acarretam o dever inexorável de reparação de tais prejuízos, de forma ampla, compreendendo tanto os danos materiais, quanto os danos morais. ${ }^{34}$

Com supedâneo nisso, o Superior Tribunal de Justiça editou a súmula $\mathrm{n}^{\circ} 37$, segundo a qual "são cumuláveis as indenizações por dano material e dano moral, oriundos do mesmo fato", entendimento que, proveniente de longa construção pretoriana, reflete o verdadeiro intuito preconizado pela Constituição da República de 1988, garantindo a ampla reparação dos danos.

32 REIS, Clayton. Dano moral. 4. ed. Rio de Janeiro: Forense, 1995, p. 72.

33 DELGADO, Rodrigo Mendes. O valor do dano moral: como chegar até ele - teoria e prática. Leme: J.H. Mizuno, 2003, p. 149.

${ }^{34}$ DELGADO, Rodrigo Mendes. O valor do dano moral: como chegar até ele - teoria e prática. Leme: J.H. Mizuno, 2003, p. 149. 
Nesse ínterim, é inegável a garantia consagrada no texto constitucional, que assegura o direito à indenização por danos morais, em caso de a vítima ser ofendida em sua honra, intimidade, imagem ou vida privada.

Os dispositivos inseridos no art. $5^{\circ}$ deixam isso claro, ressalvando, inclusive, a possibilidade de a pessoa impedir que sua intimidade domiciliar ou sua correspondência sejam violadas, na forma dos incisos XI e XII, com exceção da hipótese do art. 136, $\S 1^{\circ}$, inciso I, alínea "c", da Constituição da República.

Existem diversas situações que podem configurar ofensas à intimidade individual; Maria Helena Diniz enumera alguns exemplos: (i) violação de correspondência ou do domicílio alheio; (ii) o uso de droga ou de meios eletrônicos para compelir alguém a revelar fatos de sua vida privada ou segredos de profissão; (iii) o emprego de binóculos para fiscalizar o que ocorre no interior de uma casa; (iv) a instalação de equipamentos eletrônicos para captar conversas e imagens; (v) intrusão injustificada no retraimento ou isolamento de uma pessoa, seguindo-a, observando-a, escrevendo-lhe ou chamando-a. ${ }^{35}$

$\mathrm{O}$ direito à honra, por sua vez, assegura uma categoria de direitos inerentes à pessoa, tais como seu nome, sua reputação e sua dignidade. Assim, a honra pode ser considerada um bem alusivo ao sentimento da própria dignidade e à estimação que terceiros fazem da reputação de uma pessoa, relativamente a sua qualidade moral e a seu valor social, que pode ser afetado pela injúria, pela calúnia ou pela difamação.

\section{Fundamentos para a reparação do dano moral}

A reparação pecuniária do dano moral tem se afirmado como mecanismo de garantia da inviolabilidade de alguns atributos exteriores à vítima, que nem sempre têm definição econômica. Essa modalidade de dano significou o reconhecimento de verdadeira dimensão espiritual da pessoa humana, uma vez que aspectos personalíssimos passaram a ser preponderantes na dosimetria dos danos.

Em interessante análise da inserção humana no seio social, Marcius Geraldo de Oliveira pondera que, "como organismo biológico integrado com todos os outros sistemas vivos e não vivos da Terra, o homem participa

${ }^{35}$ DINIZ, Maria Helena. A responsabilidade civil por dano moral. Revista Literária do Direito, São Paulo, jan./fev. 1996, p. 13. 
e interage na imensa teia, destacando-se o processo mental como essencial à atividade organizadora do mundo vivo" ${ }^{36} \mathrm{E}$ conclui:

Todos os seres vivos são membros de comunidades ecológicas ligadas umas às outras numa rede de interdependência. [...] O conceito ecoético alicerça os valores espirituais do homem, visando à proteção da natureza para a autoproteção. Destacando-se a qualidade de vida como valor de fundamental importância na vida social, o homem ganha uma dimensão espiritual. E é a partir do espírito que se justificam as reparações por danos morais. ${ }^{37}$

Essa dimensão espiritual do ser humano está sempre arraigada em sentimentos que formam um arquétipo de caracteres que, se violados, redundam em danos morais, gerando dor, angústia, aflição física e espiritual, dentre vários outros padecimentos.

Mais do que isso, a dimensão espiritual "não se reduz à órbita afetiva ou de sua sensibilidade (aptidão de sentir), pois compreende também uma intelectual (aptidão de entender) e outra volitiva (aptidão de querer)" ${ }^{n 38}$, conforme ressalta Antônio Jeová Santos, transcrevendo lição de Matilde Gonzalez.

Nesse sentido, em todos os casos em que o evento danoso redunde em prejuízos de espeque moral para a vítima, serão os juízes quem fixarão as respectivas indenizações, segundo seu prudente arbítrio. Sempre partindo dessa noção, é essencial que o julgador atente-se para uma gama de circunstâncias subjetivas e objetivas do caso concreto, no intuito de aferir completamente a extensão do dano e sua repercussão para a vítima.

Algumas dessas circunstâncias já foram consagradas pela doutrina e pela jurisprudência, como a posição social e política do ofensor e do ofendido, a intensidade do ânimo empreendido pelo ofensor na causação do dano, a gravidade e a repercussão da ofensa para a vítima.

Evitando-se que o dano moral torne-se verdadeiro expediente de espertezas maliciosas, empreendidas pela pretensa vítima no afã de se locupletar ilicitamente, também se impõe a observância de alguns padrões de equidade e prudência que, necessariamente, devem nortear a análise do julgador ao avaliar as circunstâncias sociais e econômicas da vítima e do ofensor.

${ }^{36}$ OLIVEIRA, Marcius Geraldo Porto de. Dano moral: proteção jurídica da consciência. 2. ed. Leme: LED, 2001, p. 34-35.

${ }^{37}$ OLIVEIRA, Marcius Geraldo Porto de. Dano moral: proteção jurídica da consciência. 2. ed. Leme: LED, 2001, p. 34-35.

${ }^{38}$ GONZÁLEZ, Matilde M. Zavala de. Resarcimiento de daños: cuánto por daño moral. Buenos Aires: Hammurabi, 1996. v. 2, p. 66-67, apud SANTOS, Antônio Jeová. Dano moral indenizável. 4. ed. São Paulo: Revista dos Tribunais, 2003, p. 109. 
O escopo que se busca é a homogeneidade entre o valor do dano que se quer reparar e o valor do dinheiro quantificado. Em regra, inexistem parâmetros específicos para essa reparação, mas alguns critérios de bom senso são esperados dos julgadores no momento da quantificação dos danos: é preciso que a indenização não seja tão insignificante, tão simbólica, a ponto de não representar qualquer reparação, mas que seja o bastante para representar um quase-castigo e, ao mesmo tempo, propiciar uma compensação à vítima ${ }^{39}$.

Outra noção que deve fundamentar uma reparação dessa natureza é a de que a quantia fixada não pode redundar em qualquer tipo de enriquecimento injustificado, ou seja, em "uma situação que nunca se gozou, que modifique a vida do prejudicado ou da sua família, que o transforme em um novo rico. Não tão alta que pareça um gesto de induvidosa generosidade, porém com o bolso alheio". ${ }^{40}$

Deve-se ressaltar a necessidade de o julgador atentar-se para o cenário econômico do país na fixação do dano moral, tendo-se em vista as condições financeiras das partes na fixação do quantum indenizatório. Eis que, somente assim, será possível que se busque um critério equitativo nessa fixação.

\subsection{O caráter punitivo do dano moral}

Nos Estados Unidos da América, a noção punitiva do dano moral é bastante utilizada em um tipo especial de indenização exemplar: os "punitive damages".

Os "punitive damages" refletem o interesse pelo desestímulo, na condenação imposta em quantia suficiente a servir como efetiva punição ao ofensor, com o objetivo de demovê-lo da prática futura de atos semelhantes, não se remetendo, contudo, à noção de vingança, mas vigorando a ideia da educação do ofensor através da imposição punitiva.

Naquele país, há uma cultura do seguro e do resseguro que se pauta na aplicação dos "punitive damages" como verdadeiras sanções penais que, invariavelmente, ultrapassam o valor compensatório. Além disso, são apontados de modo destacado por meio de deliberação do corpo de jurados, nos casos mais graves, baseando-se no grau de culpa do agente ofensor e no sentimento de reprovação social. ${ }^{41}$

\footnotetext{
39 SANTOS, Antônio Jeová. Dano moral indenizável. 4. ed. São Paulo: Revista dos Tribunais, 2003, p. 180-181.

${ }^{40}$ SANTOS, Antônio Jeová. Dano moral indenizável. 4. ed. São Paulo: Revista dos Tribunais, 2003, p. 182.

${ }^{41}$ SOARES, Guido Fernando Silva. Common Law: introdução ao Direito dos EUA. 2. ed. São Paulo: Revista dos Tribunais, 2000, p. 29-30.
} 
No Brasil, a questão não é pacífica, justamente pelo caráter de pena que ostentam os danos punitivos, o que os tornaria incompatíveis com a própria noção de direito privado, segundo a melhor doutrina. Evidentemente, a ideia em questão liga-se à noção de desestímulo que, por sua vez, decorre da própria busca pela paz social. Esse caráter admonitório e circunstancial do quantum indenizatório reflete o intuito do instituto de lenir a dor mediante prestação pecuniária, que, se não consegue retornar as partes ao status quo ante, ao menos ameniza a lesão e pune o malfeitor, inibindo a repetição do ato danoso. ${ }^{42}$

Carlos Alberto Bittar destaca que "preenche a teoria em estudo os fins de chamar à reparação o lesante e sancioná-lo pelos danos produzidos a outrem, realçando-se, em sua base, a forte influência da Moral" "43, questão destacada, também, por Caio Mário da Silva Pereira, para o qual "o problema de sua reparação deve ser posto em termos de que a reparação do dano moral, a par do caráter punitivo imposto ao agente, tem de assumir sentido compensatório". ${ }^{44}$

Nesse aspecto, é imprescindível a consideração da gravidade da conduta praticada pelo ofensor para se delimitar seu grau de reprovação, e, por conseguinte, quantificar-se o dano moral segundo o critério punitivo. Jeová Santos acentua que, "tendo o ressarcimento uma função ambivalente - satisfatória e punitiva - têm incidência e importância a culpa e o dolo no instante da fixação do montante indenizatório". ${ }^{45}$

De fato, o aspecto valorativo do dano moral mostra-se decisivo na quantificação da avença, e o grau de reprovação, atrelado à noção de dolo ou de culpa, é um dos elementos mais importantes da análise que deve fazer o julgador. Se o ofensor laborou com culpa leve, não poderá ser penalizado da mesma forma que o ofensor que laborou com culpa grave ou gravíssima, e é aqui que se revela a importância desse caractere da liquidação do dano moral.

\subsection{Valoração do dano moral}

Os princípios de quantificação de danos patrimoniais têm se revelado incompatíveis com a valoração dos danos não-patrimoniais. Isso porque

\footnotetext{
${ }^{42}$ CAHALI, Yussef Said. Dano moral. 3. ed. São Paulo: Revista dos Tribunais, 2005, p. 33-35.

${ }^{43}$ BITTAR, Carlos Alberto. Reparação civil por danos morais. 3. ed. São Paulo: Revista dos Tribunais, 1999, p. 26.

44 PEREIRA, Caio Mário da Silva. Responsabilidade civil. 8. ed. Rio de Janeiro: Forense, 1998, p. 60.

45 SANTOS, Antônio Jeová. Dano moral indenizável. 4. ed. São Paulo: Revista dos Tribunais, 2003, p. 186.
} 
inexiste critério objetivo de aferição do quantum devido a título de danos morais, o que acaba deixando ao puro arbítrio do julgador sua dosagem, escorando-se em parâmetros subjetivos de análise da situação concreta.

Há casos em que o legislador, de antemão, traça os parâmetros a que deve se ater o julgador no momento de fixar a indenização, como ocorria na época em que ainda vigorava, no Brasil, a Lei de Imprensa. ${ }^{46}$ Por esse critério, apelidado de liquidação legal, "não se determina o montante da indenização, mas se determina em que a mesma deva consistir, ou seja, o legislador diz os critérios de determinação e medida do dano a ser ressarcido". ${ }^{47}$

Há, noutra vertente, o critério da liquidação judicial, adotado quando não existam "regras legais, que estabeleçam os elementos constitutivos da indenização, devolvendo-se a matéria, por completo ao arbítrio do julgador" ${ }^{48}$ Esse critério, comum nos casos de dano moral, confere ao julgador grandes poderes, por recair sobre ele a incumbência de fixar o valor devido.

Por certo, não seria razoável deixar ao parcial pedido da parte a proposição delimitadora do quantum ressarcível a título de danos morais. Em matéria de processo civil, não restam dúvidas acerca da vinculação do julgador aos limites do pedido, conforme preceitua o art. 128 do Código de Processo Civil, mas, sendo tão complexa a apuração dos danos morais, o mais indicado é, sim, que se conceba a liquidação judicial de seu valor, segundo o prudente arbítrio do julgador.

O grande perigo é - conforme apontado por Aparecida Amarante a insegurança jurídica que isso gera. Consciente da impossibilidade de se abandonar totalmente a noção do livre arbitramento, a autora propõe algumas regras que devem ser utilizadas pelos julgadores para nortear a fixação da quantia. São elas:

\footnotetext{
${ }^{46}$ A Lei de Imprensa - Lei ${ }^{\circ} 5.250$, de 9 de fevereiro de 1967 - foi instituída durante a ditadura militar e vigorou, no país, até 30 de novembro de 2009, quando o Supremo Tribunal Federal, no julgamento da Arguição de Descumprimento de Preceito Fundamental no ${ }^{\circ} 130$, a declarou inconstitucional por sete votos a quatro, destacando sua incompatibilidade com o sistema democrático da Constituição da República de 1988. Tal lei trazia, em seu art. 53, critérios expressos de aferição do dano moral, como a intensidade do sofrimento do ofendido, a gravidade, a natureza e repercussão da ofensa e sua posição social e política, dentre outros.

${ }^{47}$ AMARANTE, Aparecida Imaculada. Responsabilidade civil por dano à honra. 2. ed. Belo Horizonte: Del Rey, 1994, p. 259.

48 AMARANTE, Aparecida Imaculada. Responsabilidade civil por dano à honra. 2. ed. Belo Horizonte: Del Rey, 1994, p. 259.
} 
$1^{\mathrm{a}}$ regra: Que a satisfação pecuniária não produza um enriquecimento à custa do empobrecimento alheio;

$2^{\mathrm{a}}$ regra: equilíbrio entre o caso em exame e as normas gerais, de um caso em equivalência, tendo em vista:

I - curva de sensibilidade: a) em relação à pessoa que reclama a indenização; b) em relação ao nível comum, sobre o que possa produzir, numa pessoa normal, tal ou qual incidente; c) grau de educação da vítima; d) seus princípios religiosos;

II - influência do meio, considerando: a) a repercussão pública; b) posição social da vítima do dano.

$3^{\text {a }}$ regra: considerar-se a espécie do fato: se é de ordem puramente civil, se comercial, ou se envolve matéria criminal;

$4^{\mathrm{a}}$ regra: que a extensão da repercussão, seja em triplo à repercussão da notícia de que resultou o dano;

A quinta e última regra: refere-se a dano provocado por acidente físico, que acarreta a perda de órgão ou membro, ou outro prejuízo de ordem estética, [...]. ${ }^{49}$

De qualquer forma, o arbítrio judicial é preponderante na valoração do dano, não havendo espaço, em matéria de dano moral, para qualquer tipo de composição objetiva; os critérios apontados são meras sugestões de prudência, elaboradas pela autora no sentido de estabelecer algum critério para as condenações dessa natureza. Mas, no fim, sempre recai sobre o julgador a responsabilidade da dosagem da condenação.

Disso decorre a tremenda importância do bom senso dos julgadores no momento de quantificar a indenização por danos morais: sem sensibilidade, é possível que se vislumbre condenações desproporcionais, que não refletem o sofrimento que o esperado bom senso permite visualizar na vítima.

\section{Os direitos da personalidade em face do dano moral}

Conforme se asseverou, as mudanças no estado anímico da vítima, decorrentes do dano moral, não constituem o próprio dano, mas efeitos ou resultados desse. Nessa linha, o dano moral caracteriza-se como a efetiva ofensa a uma categoria de direitos e interesses que provocam os resultados anímicos que se confundem com o próprio dano.

Nesse sentido, muito se discute sobre os chamados direitos da personalidade, que a doutrina considera inatos ou inerentes ao próprio homem, existentes independentemente do direito positivo, que se limita a

49 AMARANTE, Aparecida Imaculada. Responsabilidade civil por dano à honra. 2. ed. Belo Horizonte: Del Rey, 1994, p. 261. 
reconhecê-los e sancioná-los, conferindo-lhes maior visibilidade jurídica. Isso conduz à conclusão de que, mesmo antes de serem positivados, os direitos da personalidade já possuíam proteção jurídica específica, sendo passíveis de reparação, caso fossem violados.

A origem de tais direitos, dentro do panorama constitucional, deuse com o positivismo jurídico, e seus veementes críticos das teorias sobre ideias e concepções inatas defendidas pelos teóricos do direito natural. O positivismo jurídico, negando a ideia de um só direito geral da personalidade, tratou de esmiuçar quais seriam os direitos subjetivos, positivados pelo Estado, que se enquadrariam nesse rol.

Aparecida Amarante cita lição de Vicenzo Miceli, enfatizando que os bens que compõem a personalidade são muitos, de modo que também muitos são os direitos da personalidade, e enumera os seguintes:

1) direitos (já nominados) referentes ao reconhecimento da capacidade, que constituem as condições na base das quais a pessoa pode afirmar-se no domínio do direito na qualidade de sujeito nas diversas situações da vida; 2) direito à vida, à saúde, à incolumidade pessoal; 3) direito à incolumidade espiritual e ao equilíbrio da vida do espírito; 4) direito à liberdade; 5) direito à individualização e, portanto, a todos os signos, a todos os meios que venham a diferenciar e a distinguir uma pessoa das demais; 6) direito à honra e aos bens a essa coligados ou dela dependentes, portanto à fama, ao crédito, à boa reputação e à estima pública, como manifestações externas da honra; 7) direito a uma esfera de segredo, que abranja tudo o que não pode ser comunicado a outrem, sem prejudicar, de qualquer modo, a pessoa; 8) direito ao respeito da esfera econômica, na qual a pessoa se mova como produtora de bens materiais, de forma útil, e desenvolva a sua atividade econômica; 9) direito de igualdade..$^{50}$

Estabelecendo uma segunda classificação, a autora cita o magistério de Adriano de Cupis, que, embora não tenha oferecido explicitamente uma classificação, apresentou uma análise que a enseja no estudo sistematizado dos diversos direitos, contemplando a vida e a integridade física, a liberdade, a honra e o respeito, o resguardo à identidade pessoal e o nome, dentre outros. ${ }^{51}$

Assim, a evolução do pensamento jurídico culminou com a consagração, por parte do legislador, de diversos direitos especiais da

${ }^{50}$ MICELI, Vicenzo. I diritti della personalità: la personalità nella Filosofia del Diritto. Milão: Società Editrice, 1922, p. 382-383, apud AMARANTE, Aparecida Imaculada. Responsabilidade civil por dano à honra. 2. ed. Belo Horizonte: Del Rey, 1994, p. 118.

51 DE CUPIS, Adriano. I diritti della personalità: trattato di diritto civile e comerciale, Milão: Giuffrè, 1973. v. 4, t. 1, p. 63 et seq, apud AMARANTE, Aparecida Imaculada. Responsabilidade civil por dano à honra. 2. ed. Belo Horizonte: Del Rey, 1994, p. 122. 
personalidade, inseridos no ordenamento jurídico para salvaguardar bens jurídicos específicos, como a vida, a integridade física, a liberdade e a honra, sem se esgotar em um rol fechado.

Com o fim da Segunda Grande Guerra, novas tendências jurídicas surgiram no mundo, e boa parte da doutrina, preocupada com os impactos gerados pelas atrocidades cometidas durante o conflito e com o crescimento da sociedade consumerista, passou a buscar uma cláusula geral dos direitos da personalidade, que, com o tempo, surgiu nas constituições e nos dispositivos infraconstitucionais de vários países. Evidentemente, o Brasil seguiu essa tendência.

O art. $1^{\circ}$, inciso III, da Constituição da República de 1988, é bom exemplo dessa tendência, ao estabelecer, como fundamento da república, a dignidade da pessoa humana. Tal expressão, extremamente complexa, sintetiza todos os caracteres inerentes à pessoa, em sua complexidade $\mathrm{e}$ diversidade de manifestações. Ademais, o já mencionado art. $5^{\circ}$, inciso $\mathrm{X}$, alude a uma gama de outros direitos da personalidade, quando trata da intimidade, da vida privada, da honra e da imagem.

$\mathrm{Na}$ mesma toada, o art. $5^{\circ}$, em seu inciso III, preconiza a proibição da tortura e do tratamento degradante; em seu inciso XLIX, assegura o respeito à integridade física e moral dos presos; nos incisos IV e IX, assegura a liberdade de expressão; no VIII, garante a liberdade de crença religiosa ou convicção política ou filosófica.

Segundo Caio Mário da Silva Pereira, a Constituição estabeleceu o mínimo, quando alude a tais direitos da personalidade, mas o rol lá inscrito não o é em "numerus clausus" (rol fechado). Ainda segundo o autor, os direitos da personalidade não podem ser reduzidos, por via legislativa, porque estão inscritos na Constituição. ${ }^{52}$

Isso conduz a uma importante reflexão: mais que à lei, compete à doutrina e à jurisprudência identificar tais direitos da personalidade, partindo das situações cotidianas, posto que, num mundo globalizado, a cada dia um novo aspecto da personalidade destaca-se e passa a ser juridicamente tutelado, o que inviabiliza qualquer tentativa de esgotamento da enumeração de tais direitos.

Tais considerações são importantíssimas para destacar que o dano moral, enquanto instituto jurídico e, nas linhas gerais apresentadas nos tópicos anteriores, está conectado à violação de um ou de alguns direitos da personalidade. Essa noção é fortemente difundida pela doutrina, a

52 PEREIRA, Caio Mário da Silva. Responsabilidade civil. 8. ed. Rio de Janeiro: Forense, 1998, p. 65. 
exemplo de Sérgio Cavalieri Filho, que destaca que "o dano moral é lesão de bem integrante da personalidade, tal como a honra, a liberdade, a saúde, a integridade psicológica, causando dor, sofrimento, tristeza, vexame e humilhação à vítima". ${ }^{53}$

Antonio Jeová Santos observa que: "Num sistema que coloca o homem como epicentro do direito, o reconhecimento do dano moral, como entidade passível de gerar indenização, é o coroar do reconhecimento dos direitos da personalidade". ${ }^{54}$

Yussef Said Cahali, a seu turno, considera mais razoável que a caracterização do dano moral se dê a partir de seus próprios elementos, tais como "a privação ou diminuição daqueles bens que têm um valor precípuo na vida do homem e que são a paz, a tranqüilidade de espírito, a liberdade individual, a integridade individual, a integridade física, a honra e os demais sagrados afetos" ${ }^{25}$. Tais posicionamentos elucidam a necessidade de classificação dos danos morais com base nos aspectos subjetivos, ligados ao plano valorativo do indivíduo, no meio social em que repercute o fato violador, afetando sua reputação no meio social em que vive.

Conforme leciona Cahali, sendo "multifacetário o ser anímico, tudo aquilo que molesta gravemente a alma humana, ferindo-lhe gravemente os valores fundamentais inerentes à sua personalidade ou reconhecidos pela sociedade em que está integrado, qualifica-se, em linha de princípio, como dano moral". ${ }^{56} \mathrm{E}$, diante da própria dificuldade de enumeração de seus casos, deve-se dar ampla interpretação ao rol dos direitos da personalidade.

Wilson Melo da Silva traz vastos exemplos das denominações dadas ao instituto nos ordenamentos jurídicos europeus, como o "dommage moral" ou "préjudice moral" dos franceses, o "daño moral" dos espanhóis e o "danno morale" dos italianos. Diz, também, que, tomando por base a definição dos danos em questão por meio dos direitos da personalidade, talvez fosse mais adequada a denominação de dano à pessoa, para assinalar a ofensa. ${ }^{57}$

Comparativamente, tem-se o modelo do common law, de países como a Inglaterra e os Estados Unidos da América, onde se faz uma nítida

\footnotetext{
${ }^{53}$ CAVALIERI FILHO, Sérgio. Programa de Responsabilidade Civil. 8. ed. São Paulo: Atlas, 2009, p. 74.

${ }^{54}$ SANTOS, Antônio Jeová. Dano moral indenizável. 4. ed. São Paulo: Revista dos Tribunais, 2003, p. 57.

${ }^{55}$ CAHALI, Yussef Said. Dano moral. 3. ed. São Paulo: Revista dos Tribunais, 2005, p. 20.

${ }^{56}$ CAHALI, Yussef Said. Dano moral. 3. ed. São Paulo: Revista dos Tribunais, 2005, p. 22.

${ }^{57}$ SILVA, Wilson Melo da. O dano e sua reparação. 3. ed. Rio de Janeiro: Forense, 1983, nº 1, p. 12.
} 
distinção entre o dano à pessoa ("personal tort"), que abrange os danos, de um modo geral, à reputação, aos sentimentos da pessoa, e o dano à propriedade ("property tort"), que se refere aos danos à propriedade e ao patrimônio material em geral. Porém, tal denominação certamente não está isenta de críticas, pois, "do ponto de vista semântico, a expressão dano à pessoa não é excludente dos danos patrimoniais indiretos decorrentes da lesão sofrida pela pessoa". ${ }^{58}$

A natureza não-patrimonial dos direitos da personalidade e a circunstância de serem inatos e essenciais à realização da pessoa tornamnos direitos eminentemente singulares e eivados de características próprias e essenciais: absolutividade, generalidade, intransmissibilidade, indisponibilidade, originalidade, vitaliciedade, irrenunciabilidade, inexpropriabilidade e imprescritibilidade.

Sem adentrar especificamente a cada uma dessas características, insta destacar que são direitos inatos e originários porque coincidem com a existência da pessoa, enquanto sujeito de direito. São direitos da própria existência, que têm vigência efetiva a partir do nascimento. ${ }^{59}$

Também são reputados como absolutos porque dotados de eficácia erga omnes, irradiando efeitos em todos os campos e impondo a todos o dever de os respeitar; são gerais por serem direitos outorgados a todas as pessoas, simplesmente pelo fato de existirem; são intransmissíveis e irrenunciáveis porque seu exercício não pode sofrer limitação voluntária, conforme reza o art. 11 do Código Civil; são extrapatrimoniais por serem direitos que prescindem de conteúdo patrimonial, ainda que sua lesão gere repercussões econômicas; são imprescritíveis porque sua aquisição não está condicionada a qualquer decurso de prazo, e vitalícios, por serem permanentes, acompanhando o ser humano desde a concepção até sua morte.

Nesse diapasão, em razão da interdependência com os direitos da personalidade, os danos de natureza moral nunca poderão se apresentar pura e simplesmente como meio de reparação, pois a lesão ao direito da

${ }^{58}$ SILVA, Wilson Melo da. O dano e sua reparação. 3. ed. Rio de Janeiro: Forense, 1983, nº 1, p. 12.

${ }^{59}$ Hodiernamente, as teorias natalista e da personalidade condicional não encontram sustentáculos na doutrina e na legislação civil, de modo que prevalece o entendimento de que a teoria concepcionista, que propõe uma interpretação do art. $2^{\circ}$ do Código Civil em conformidade com a Constituição da República de 1988, deve prevalecer. Assim, a moderna doutrina defende que, desde a concepção intrauterina, já se consolidam todos os atributos existenciais da pessoa. Portanto, embora a titularidade de direitos reais e patrimoniais dependa do nascimento com vida (capacidade), independentemente do nascimento com a vida, a pessoa já é titular de situações existenciais (personalidade). (Cf. VIANNA, Guaraci de Campos. O nascituro como Sujeito de Direito, início da personalidade civil: proteção penal e civil. Revista Ensaios Jurídicos, IBAJ, Rio de Janeiro, v. 1, n. 1, 1996, p. 288-301). 
personalidade não pode ser mensurada monetária e economicamente, como outros direitos subjetivos.

Por isso, a indenização a título de danos morais, na hipótese, tem função compensatória, que não pode ser meramente simbólica. Vale dizer: para que a compensação seja efetiva e produza o desestímulo no lesante, sem, contudo, conduzir ao enriquecimento sem causa do lesado.

Em outras palavras, ao se isolar os direitos da personalidade, como direitos essenciais da pessoa e estritamente ligados a sua dignidade, não se está a dizer que não se possa postular a indenização por danos morais, pois os direitos da personalidade surgem associados aos outros direitos que foram violados, ainda quando não sejam tão visíveis, tais como a vida, a liberdade, a integridade física, a integridade psíquica, a reputação, ou a identidade pessoal, dentre muitos outros.

Quando se diz que os danos morais são inerentes aos direitos da personalidade, rememoram-se as vicissitudes por que passaram, sempre esbarrando na ausência de mecanismos viáveis de tutela jurídica na dogmática civilista, o que somente se modificou nas décadas finais do século XX, com a recepção constitucional dos danos morais, que representam o "elo de ligação", a sanção adequada ao descumprimento do dever absoluto de abstenção que os direitos da personalidade impõem erga omnes.

\section{A questão dos danos morais sofridos pela pessoa jurídica}

À guisa de conclusão, insta comentar brevemente a situação da pessoa jurídica e o curioso questionamento acerca da possibilidade de que venha a sofrer ou não danos de natureza moral.

$\mathrm{O}$ direito positivo, há tempos, já reconhece a personalidade jurídica dos entes abstratos, atribuindo-lhes a capacidade de direitos e obrigações nas relações jurídicas de que são partes, dando-lhes existência no plano jurídico. Daí, surgiram as várias teorias que tentaram delimitar os pressupostos existenciais dos entes abstratos: (i) a teoria da ficção, pela qual a pessoa jurídica seria mera ficção criada pela lei, porquanto a qualidade de sujeito da relação jurídica é inerente unicamente ao homem; (ii) a teoria da propriedade coletiva; (iii) a teoria institucional, que preconiza a existência da ordem social para o preenchimento de finalidade de cunho socialmente útil; (iv) a teoria da realidade, segundo a qual o ente coletivo é uma realidade viva no mundo atual. ${ }^{60}$

${ }^{60}$ AMARANTE, Aparecida Imaculada. Responsabilidade civil por dano à honra. 2. ed. Belo Horizonte: Del Rey, 1994, p. 201. 
A teoria da realidade foi a de maior aceitação doutrinária, sendo defendida por juristas do calibre de Raymond Saleilles, Louis Josserand, Marcel Planiol, Georges Ripert e Henri Capitant, dentre vários outros, que sustentam a consideração da pessoa jurídica como mais que mera ficção: é uma realidade viva, integrante da vida social, revestida de dignidade civil e circundada de reputação. ${ }^{61}$

Evidentemente, as pessoas jurídicas não poderiam sofrer dano moral se este supusesse, necessariamente, os fenômenos psíquicos e espirituais que somente se manifestam na pessoa humana. Todavia, exatamente pelo fato de tais reações psicológicas não se confundirem com o dano moral, é que as pessoas jurídicas podem vir a sofrer dano dessa natureza.

No Brasil, o Superior Tribunal de Justiça, sanando quaisquer dúvidas a respeito da questão, editou o enunciado ${ }^{\circ} 227$ de sua Súmula, segundo o qual "a pessoa jurídica pode sofrer dano moral". Tal entendimento, objeto de intrincada construção pretoriana, reflete o que preconiza o Código Civil de 2002, em seu art. 52, in verbis: "Aplica-se às pessoas jurídicas, no que couber, a proteção dos direitos da personalidade".

Há, como se vê, um juízo de aplicação analógica da sistemática dos direitos da personalidade à pessoa jurídica, decorrente de lei. Nesse sentido, doutrina e jurisprudência entendem que a pessoa jurídica é titular de honra objetiva, que representa sua reputação no meio social, particularmente no mercado em que exerce suas atividades. Tal conceito é bastante diferente da honra subjetiva, que se caracteriza pelo sentimento de dignidade intrínseco à pessoa humana, segundo um juízo psíquico ou anímico. ${ }^{62}$

Este é o posicionamento defendido por Antonio Jeová Santos:

Outro equívoco, no entender que a pessoa jurídica não pode padecer dano moral, é a conclusão errônea, sem embargos da fama de seus adeptos, na direção de que a configuração do dano moral somente ocorre quando existe repercussão na psique de uma pessoa. Também é dano moral qualquer violação a direitos personalíssimos e, estes, por analogia, as pessoas jurídicas os têm. ${ }^{63}$

E, aprofundando-se na análise desses caracteres analogicamente garantidos pela proteção constitucional, o autor exemplifica: "a tutela ao nome, à marca, à honra em seu aspecto objetivo, à liberdade de ação, à

${ }^{61}$ AMARANTE, Aparecida Imaculada. Responsabilidade civil por dano à honra. 2. ed. Belo Horizonte: Del Rey, 1994, p. 201.

${ }^{62}$ CAHALI, Yussef Said. Dano moral. 3. ed. São Paulo: Revista dos Tribunais, 2005, p. 342 e ss.

${ }^{63}$ SANTOS, Antônio Jeová. Dano moral indenizável. 4. ed. São Paulo: Revista dos Tribunais, 2003, p. 141. 
intimidade, tanto que os segredos industriais gozam de especial proteção". ${ }^{64}$ Com isso, sempre que forem vilipendiados tais aspectos integrantes da pessoa jurídica, deve-se conferir-lhe proteção, sujeitando o ofensor ao pagamento dos danos de ordem moral que vier a causar.

Em outras palavras, é de se concluir que as pessoas jurídicas, assim como as pessoas físicas ou naturais, também possuem bens patrimoniais e não-patrimoniais. Há bens patrimoniais corpóreos, como o maquinário, as instalações e materiais utilizados no desempenho da atividade, mas também existem os bens patrimoniais incorpóreos, que são aqueles exemplificados anteriormente. ${ }^{65}$

Insofismavelmente, esse patrimônio imaterial está ligado ao renome da pessoa jurídica, sendo resultado da boa qualidade de seus produtos ou dos serviços prestados, de sua eficiência organizacional, do modo como lida com seus empregados e clientes, e até mesmo dos investimentos publicitários que realiza.

Dito isso, é marcante a lição de Jeová Santos quando diz que tal ofensa pode diminuir o conceito público de que goza a pessoa jurídica no meio social, sem que haja repercussão específica e direta em seu patrimônio, e tal dano, embora puramente não-patrimonial, "existe e pode ser mensurado através de arbitramento". ${ }^{66}$

Feitas tais considerações, é de se concluir que a Constituição da República de 1988 é enfática ao açambarcar, também, as pessoas jurídicas como entes passíveis de sofrerem lesão danosa a sua moral, enquanto sociedade coletiva de reputação ilibada, incólume, permitindo-se que ofensas a sua imagem traduzam-se em danos morais indenizáveis.

\section{Conclusão}

Durante séculos, embora a noção de ofensa a bens não-patrimoniais dos indivíduos fosse cogitada por outros ramos do saber, notadamente quando surgiram os estudos da Antropologia e da Psicologia, o Direito evoluía alheio a esse ideal.

Durante a exploração das bases históricas do dano moral, foi possível verificar que mesmo algumas sociedades antigas já pregavam a imposição

${ }^{64}$ SANTOS, Antônio Jeová. Dano moral indenizável. 4. ed. São Paulo: Revista dos Tribunais, 2003, p. 141.

${ }^{65}$ AMARANTE, Aparecida Imaculada. Responsabilidade civil por dano à honra. 2. ed. Belo Horizonte: Del Rey, 1994, p. 207.

${ }^{66}$ SANTOS, Antônio Jeová. Dano moral indenizável. 4. ed. São Paulo: Revista dos Tribunais, 2003, p. 145 . 
de punições pecuniárias para ofensas deflagradas contra a honra, por exemplo. Contudo, não existia um verdadeiro instituto jurídico que revelasse a importância dessa espécie de dano. Tudo decorria da simples lógica sincrética de que se deveria impor algum tipo de "pena" a quem praticasse atos reputados ofensivos à cultura e aos costumes daqueles povos.

No Direito Civil moderno, conforme se abordou, a completa compreensão dos direitos da personalidade consolidou-se quando do desenvolvimento da doutrina dos danos morais, que jungiu um mecanismo sancionatório até então inexistente às hipóteses de lesão ou ofensa a tais direitos.

No Brasil, essa evolução jurídica foi verificada em premissas iniciais com o Código Civil de 1916, mas somente recebeu verdadeiro reconhecimento do ordenamento jurídico com o advento da Constituição da República de 1988, que expressamente insculpiu o dano moral dentro do rol de direitos e garantias fundamentais do art. $5^{\circ}$, conferindo-lhe enorme força normativa.

Com o amadurecimento da doutrina na sistemática civil hodierna, direitos da personalidade e danos morais evoluíram atrelados, denotando sua relação de proximidade, que fez surgir, da parte de muitos juristas, questionamentos acerca da possibilidade de existirem danos morais fora do âmbito dos direitos da personalidade.

Essa indagação foi refutada pela doutrina, após investigação mais detida da interligação entre os dois institutos. Ao analisá-los, foi possível notar que o que concerne à esfera psíquica ou íntima da pessoa humana, ou seja, seus sentimentos, sua consciência ou sua dor, correspondem a alguns dos aspectos essenciais da honra e da reputação, espécies de direitos da personalidade. A noção de dano moral não se encerra nisso!

Ao longo da investigação realizada com o presente trabalho, foi possível constatar que a ideia de dano moral remete à violação do dever de abstenção, imponível erga omnes, de violação a direitos da personalidade. Ademais, o rol desses direitos, como se viu, não é taxativo, tampouco exíguo.

O estudo específico da situação das pessoas jurídicas permitiu ilustrar com clareza que os direitos da personalidade não se limitam pela noção simplista de que a concepção jurídica de personalidade apenas corresponde a aspectos da psicologia humana.

Com isso, revela-se clara a visceral inerência dos danos morais aos direitos da personalidade. Vale dizer: os danos morais nunca se apresentam 
como verdadeira reparação, uma vez que a lesão ao direito da personalidade não pode ser medida economicamente; por isso, a indenização a título de danos morais tem função precipuamente compensatória, que não pode ser simbólica, para que a compensação seja efetiva e produza impacto negativo no lesante, nem demasiada, para não conduzir ao enriquecimento sem causa do lesado.

\section{Il danno morale e la sua inerenza ai diritti della personalità}

Riassunto: Le dificoltà nella comprensione dell'estenzione e delle caratteristiche dei diritti della personalità, che mancavano meccanismo vitale per la tutela giuridica, hanno causato l'evoluzione del Diritto alla discrezione di questi diritti. Quindi, lo sviluppo della dottrina dei danni morali ha rappresentato il link mancante per unire la comprensione che si aveva su questi diritti ad un meccanismo sanzionatorio, così importante nella sistematica civile odierna che ha dato origine à la discussione circa la possibilità di esistere fuori dei diritti della personalità. Pertanto, si analizzerà il concetto del danno morale, l'origine storica, i suoi fundamenti, il suo modo di quantificazione, ed anche la sua posizione nel sistema giuridico brasiliano per concluire, in fine, opporlo ai diritti della personalità.

Parole chiave: Danno morale. Diritti della personalità. Costituzione della Repubblica di 1988. Responsabilità civile. Inerenza.

\section{REFERÊNCIAS}

AMARANTE, Aparecida Imaculada. Responsabilidade civil por dano à honra. 2. ed. Belo Horizonte: Del Rey, 1994.

BITTAR, Carlos Alberto. Reparação civil por danos morais. 3. ed. São Paulo: Revista dos Tribunais, 1999.

CAHALI, Yussef Said. Dano moral. 3. ed. São Paulo: Revista dos Tribunais, 2005.

CARMO, Júlio Bernardo do. O dano moral e sua reparação no âmbito do direito civil e do trabalho. Revista LTr, São Paulo, mar. 1996. 
CAVALIERI FILHO, Sérgio. Programa de responsabilidade civil. 8 . ed. São Paulo: Atlas, 2009.

DELGADO, Rodrigo Mendes. O valor do dano moral: como chegar até ele - teoria e prática. Leme: J.H. Mizuno, 2003.

DIAS, José de Aguiar. Da responsabilidade civil. 11. ed. Rio de Janeiro: Renovar, 2006.

DINIZ, Maria Helena. A responsabilidade civil por dano moral. Revista Literária do Direito, São Paulo, jan./fev. 1996.

MAZEAUD, Henri; MAZEAUD, León; TUNC, André. Traité théorique et pratique de la responsabilité civile, délictuelle et contractuelle. 3. ed. Paris: Librairie du Recueil Sirey, 1938.

OLIVEIRA, Marcius Geraldo Porto de. Dano moral: proteção jurídica da consciência. 2. ed. Leme: LED, 2001.

PEREIRA, Caio Mário da Silva. Responsabilidade civil. 8. ed. Rio de Janeiro: Forense, 1998.

REIS, Clayton. Dano moral. 4. ed. Rio de Janeiro: Forense, 1995.

SANTOS, Antônio Jeová. Dano moral indenizável. 4. ed. São Paulo: Revista dos Tribunais, 2003.

SAVATIER, René. Traité de la responsabilité civile en droit français. Paris: Librairie Génêrale de Droit et de Jurisprudence, 1951. t. I.

SILVA, Américo Luís Martins da. O dano moral e a sua reparação civil. São Paulo: Revista dos Tribunais, 1999.

SILVA, Wilson Melo da. O dano e sua reparação. 3. ed. Rio de Janeiro: Forense, 1983. 
SOARES, Guido Fernando Silva. Common Law: introdução ao Direito dos EUA. 2. ed. São Paulo: Revista dos Tribunais, 2000.

VIANNA, Guaraci de Campos. O nascituro como Sujeito de Direito, início da personalidade civil: proteção penal e civil. Revista Ensaios Jurídicos, IBAJ, Rio de Janeiro, v. 1, n. 1, 1996.

ZENUN, Augusto. Dano moral e sua reparação. 3. ed. Rio de Janeiro: Forense, 1995.

目 Recebido: setembro/2013. Aprovado: dezembro/2013. 